\title{
8. Propertied Citizenship in a Township and Suburb in Johannesburg Barbara Heer
}

\begin{abstract}
This chapter uses three different approaches to talk about middle class in two South African neighbourhoods (a white suburb and a black township). Firstly, I argue that property ownership is an important signifier of middleclassness which is yet underemphasised in debates about African middle classes. Based on an ethnographic comparison, I explore property ownership and middleclassness as social categories. Secondly, I approach social differentiation as it evolves in everyday urban lives through the concept of relational micromilieus (Hradil 1999) embedded in different urban spaces, namely in various neighbourhoods. Thirdly, I use the class definition of Seekings and Nattrass (2005), who developed a nine-fold classification scheme for South Africa based on occupational groups in the Weberian tradition, to point out socio-economic differences between the two groups in focus. The cases from Johannesburg presented in this chapter highlight the relationship between spatial arrangements and political attitudes in two contrasting social milieus the diverging social trajectories of which need to be viewed in the context of South Africa's past. The two milieus discussed in this chapter are surprisingly similar concerning their relationship to property ownership and display conservative political attitudes.
\end{abstract}

\section{Introduction}

The multifaceted city of Johannesburg is home to many diverging, yet deeply connected and interrelated social worlds that need to be understood in relation to urban history. Apartheid, the South African system of racial segregation (1948-94), bestowed privileges to those categorised as 'white', like access to good education, good jobs, and high quality housing. 
Apartheid enabled white middle class families to live in low-density suburbs that afforded them high levels of privacy and substantial personal space. For those categorised as 'black', apartheid came along with the expropriation of property rights and many other attacks on their privacy. Economic, social, and spatial inequalities continue to be a political and social challenge in the post-apartheid decades. Space, race, and class persist in being intertwined in South Africa (Ballard, 2002; Teppo, 2009). In my study, two settings are under closer inspection: a township which was assigned for the non-white population ('black', 'Indian,' 'coloured'), and a suburb which once hosted a 'white'-only population. Upward social mobility is strongly associated with space as exemplified in the following statement by a female hostel dweller from the township of Alexandra:

If I had a lot of money, I would buy a house in the suburb. If you got much money, your lifestyle starts changing also. You can now stay alone in your house, you don't care about your neighbours, and you won't ask others for anything. I think that's how suburb life is like.

In post-apartheid Johannesburg, many black township dwellers aspire to move to a suburb and own a house. They believe that improving one's life should ideally go along with an enlargement of private space. Owning a house is therefore a key signifier of doing economically well; it symbolizes a move out of poverty. Property ownership is intertwined with notions of privacy: for many Johannesburg residents, becoming middle class or affluent entails being less dependent on others and minding 'one's own business'. Many, though, consider middle class status to have socially detrimental aspects, like social isolation and decreasing social control. In this city, where privacy for a large part of the population has been contested for decades, the desire to own property can be seen as a desire to construct a hard-edged embodiment of the private sphere, and to establish a spatial form to delimit one's sphere of social control (Madanipour, 2003, pp. 53, 59). 
The first key argument of this chapter is that property ownership is an important signifier of middleclassness and form of privilege which is yet underemphasised. By property ownership, I mean the varied phenomena ranging from legal property ownership as defined by law to diverse social tenure practices (also called 'informal' forms). As the ethnography will show, property ownership is far from being only an economic asset. Property has social, cultural, and political significance.

The second key argument zooms in on the political consequences of ownership. Property ownership in Johannesburg is the base on which urban dwellers position themselves politically. Ownership leads to a sense of political entitlement, which I follow Roy (2003) in calling 'propertied citizenship'. As the two ethnographic examples from Johannesburg show, propertied citizenship turns middle classes into highly conservative forces which oppose propoor urban policies. Although neither all property owners belong to middle classes, nor do all middle class groups own property, ownership is a signifier for middleclassness. It therefore needs to be included more thoroughly in debates about social differentiation in African societies.

In this chapter, I conduct a disjunctive comparison of two property-owning milieus in Johannesburg. I approach social differentiation as it evolves in everyday urban lives through the concept of relational micro-milieus embedded in different urban spaces, namely in various neighbourhoods. I understand social milieus as groups of like-minded people who share similar values, lifestyles, and relationships to others (Hradil,1999, p. 420). Milieus constitute the sphere of the lifeworld in which forms of action and meanings are shared, familiar, known and normal to everyone (Förster, 1997).

One of the two milieus lives in the township Alexandra, and the other in the affluent (and formerly white) neighbourhood of Linbro Park. What both milieus share is that property ownership is for both key for distinguishing themselves from others socially, politically and 
economically. The descendants of former property owners in Alexandra are engaged in a legal fight with the government for the restoration of property rights that were expropriated during apartheid. The property owners of Linbro Park are opposed to the post-apartheid government's plan to construct public housing for the poor in their neighbourhood. Both groups' political practices slow down the implementation of an urban renewal project geared to poverty reduction. The chapter concludes that their property ownership and propertied citizenship caused their similarly "hindering" stances against the urban renewal project.

The cases compared here are part of the wider story of the emergence of a global middle class. Conventional conceptions of this class have attracted widespread criticism. Many conceptions of the global middle class are fundamentally Eurocentric; the metropolitan theory that underlies them is not placeless and universal as it pretends, but highly contextual (Connell, 2007). Anthropologically driven critiques examine the supposed 'classes' in terms of their actual lifestyles, statuses, and identities. Like other anthropologists, I consider it more fruitful to empirically explore the lifestyles and signifiers of middleclassness than to solve the definitional and theoretical conundrums of the 'middle class'.

My comparison here is 'disjunctive' (Lazar, 2012). That is, I compare millieus which many would judge as incommensurable for at least three reasons. First, the two cases do not constitute groups representative for African middle classes in a statistical sense. Second, the two cases are embedded in contexts that are generally not studied under the same research frameworks, namely a white suburb and a black township. ${ }^{1}$ Third, the comparison juxtaposes some points for one milieu in the present against the other milieu in the past. So this

\footnotetext{
${ }^{1}$ While research on suburbs tends to focus on issues like gated communities, neighbourhood associations and private security governance, township studies tend to contribute to debates on urban poverty, urban violence, and political protests.
} 
comparative endeavour stands in sharp contrast to quasi-monolithic, coherent, hard-science comparisons (Fox and Gingrich, 2002). What I employ here is a methodology emerging out of the new comparative urban anthropology (Robinson, 2011; Heer, 2015a). An important critique of hard-science comparisons is that comparison of groups (be it middle classes or social milieus) run the risk of making a 'snap shot' of social differentiation at a particular moment, and missing the chance to analyse change and process. In this ethnographic comparison, I therefore do not take the units of comparison 'as discrete, homogenous and stable entities', but as 'differentiated, changing results of wider developments, within their fuzzy boundaries' (Fox and Gingrich, 2002, p. 19; see also Scheffer and Niewöhner, 2008; Handler 2009). I compare the milieus not with regards to their 'groupness', but with regard to their relationship with property ownership.

\section{The two sites on closer inspection}

Alexandra and Linbro Park are located in the Region E, in the north-east of the City of Johannesburg. Alexandra, a former freehold township, is home to about 340,000 inhabitants (Alexandra Renewal Project 2005). Linbro Park is about half this geographical size, and has a population of only 1-2,000 inhabitants (my estimate). My $\mathrm{PhD}$ research showed that although the poor township and the affluent suburbs are usually represented as disconnected and segregated, there are many connections and interdependencies. There are economic, social, and even religious interconnections which play themselves out in ambivalent and contested spaces and encounters: work, shopping malls, and churches (Heer, 2015a, 2015b). A further 
link between the two areas is an urban renewal project, the Alexandra Renewal Project $(\mathrm{ARP}) .^{2}$

The ARP was inaugurated in 2001 with the mandate to upgrade the urban infrastructure and to provide public housing for those residents in Alexandra who were living in deteriorated and overcrowded dwellings. In the transition from apartheid to majority rule, public housing has become an important signifier for socio-political change. The 'Reconstruction and Development Programme' (RDP) and the later 'Breaking New Ground' policy (2004) established the provision of so-called 'RDP housing' (public housing for the poor) as one of the most visible and most politicised domains of social welfare. The ARP was equipped with R1.3 billion (about 80 million euros) and had considerable support from the ruling ANC party (Sinwell, 2010, pp. 30-1). Corruption, leadership problems, and the lack of nearby affordable urban land slowed progress. The slow implementation was worsened by the lack of cooperation and resistance of some urban dwellers. The resistant groups are the focus of the following sections.

\section{Alexandra}

Alexandra is often - like many neighbourhoods described as 'slums' or 'ghettos' (Castañeda, 2012) - characterised as 'crime-ridden' and 'poor'. There is indeed a high level of structural unemployment, high crime rates, and a densely populated, largely decaying housing stock. Poverty, though, is a relational and relative category (Spittler 1991). A survey by Everatt (2009) shows that in comparison to rural areas, the standards of living in Alexandra are

\footnotetext{
${ }^{2}$ The ARP was long an intergovernmental entity and part of a national Renewal Programme. In 2014/2015 (after the data for this study was collected) the ARP became merged with the Johannesburg Development Agency.
} 
actually high, not least because of the proximity to many urban services. Income alone is a poor indicator for assessing social differentiation in Alexandra (see Neubert und Stoll in this volume). The social and political divisions in the township go beyond standard categorisations of class or ethnicity. Rather, they are related to the history of waves of immigration, different types of accommodation, and shifting categorisations of the inhabitants by the apartheid and post-apartheid governments (Bonner and Nieftagodien, 2008; see also Crankshaw, 1996b). One of these important axes of differences is property ownership, which expresses itself in a key social relation: namely the relation between landlords and tenants.

\section{Alexandra's property owners}

In 1912 a European property investor bought the land of Alexandra and declared it as a 'freehold' township, where non-whites were allowed to acquire land (for more details see Bonner and Nieftagodien, 2008). ${ }^{3}$ Being one of the few places where Africans could still buy urban land after the 1913 Natives Urban Land Act was introduced, Africans from rural and urban areas made use of this opportunity. Some had been commercially successful farmers and bought the land with the money made from selling their cattle. Others had been to missionary schools and belonged to the small black petty urban bourgeoisie; they moved to Alexandra from other parts of the city (Bonner and Nieftagodien, 2008, pp. 5, 22).

In white supremacist South Africa, owning property for black urbanites was an exceptional and contentious privilege (Bonner and Nieftagodien, 2008, p. 4). In order to pay

\footnotetext{
${ }^{3}$ During apartheid, the other freehold townships of Johannesburg (e.g. Sophiatown, Newclare, and Martindale) were erased. This is why little is known about the history of freehold townships or the affluent black African groups who lived in them (Bonner and Nieftagodien, 2008, p. 5).
} 
off their bonds, the property owners rented out rooms to the many poorer Africans who came to seek a better life in the city. From the rents, owners paid their own living expenses, which made them independent from paid work. Many property owners started businesses on their plots. ${ }^{4}$ Property ownership was hence key to creating a middle class in this township which could be said to have occupied 'an intermediate position between white capital and the African working class, and between the state and the black population it ruled' (Southall, 2014, p. 298).

Their economic and social position of Alexandra's property owners was increasingly contested from the 1930s, and even more so during apartheid. Because of suburban growth, Alexandra was increasingly surrounded by white-zoned suburbs and it became colloquially called a 'black spot'. As one elderly property owner recalled, 'We were the only black people to own property then. The government didn't like that at times, that's why they wanted to destroy Alexandra.'

Their white suburban neighbours started to see overcrowded Alexandra as a source of disease and 'out of control'. There were four attempts by the state to remove the township in 1940, 1943, 1950 and 1979 (Curry, 2012, p. 7; Bonner and Nieftagodien 2008). During apartheid, property was expropriated and tens of thousands of people were removed to other townships. Most had lost the economic base to maintain middle class status by the 1970 s.

\footnotetext{
${ }^{4}$ In the life history interviews conducted for the Alexandra History Project the typical life trajectory which emerged was 'that of the sharecropper turned urban businessman and entrepreneur in Alexandra' (Bonner and Nieftagodien, 2008, p. 5). There is a strong link between liquidated rural assets, urban property ownership, and urban entrepreneurship (Bonner and Nieftagodien, 2008, p. 4).
} 
Many disenfranchised property owners who were not removed remained in their houses, albeit without formal property rights. They officially became tenants of the municipality and were forced to pay rent (Bonner and Nieftagodien, 2008, p. 193 ff.). Despite expropriation, those who remained continued to have privileged access to space in the increasingly densely populated township. And, they continued to practice exclusive control of space by exercising 'informal' property rights and demanding rent from tenants of their former properties; sometimes their 'ownership' was contested and sometimes it was socially legitimated. When former property owners could not socially re-establish their power over space, tenants turned themselves into landlords by subletting shacks that they constructed adjacent to their own quarters. Negotiations and conflicts related to this complex and dynamic web of informal property rights characterise everyday life in Alexandra until today.

During apartheid, former landlords usually had a higher living standard than tenants. For example, they probably owned a television. On work days, working class tenants left for jobs in the city or suburbs while middle class landlords remained 'at home' to collect rents, look after their businesses, and take care of many political affairs. Today, the descendants of the 2,400 or so former property-owning families still occupy a better social position relative to both new shack-dwellers and very poor long-term residents. Many still act as 'informal' landlords and extract rent. This small but stable flow of cash into their households may be one of the reasons why many of the descendants of former property owners have enjoyed a relatively good education. Some descendants of former property owners can even send their children to private schools in the suburbs. University degrees, though, are rare.

For example, Mpo, a 31-year-old descendant of property owners, finished high school and even completed some college courses. He is more educated than most of his neighbours. He lives with his girlfriend and child in a backyard room on the plot that used to be his father's property. Mpo and his family can only subtly be distinguished from their neighbours 
in overall 'lifestyle'. Like many other young men in Alexandra, Mpo's twenties were marked by drug abuse and criminal activity. His child, too, is growing up in the same difficult social and physical surroundings as Mpo's tenants. They all lack private space and all experience the social problems characteristic of the township. Nevertheless, Mpo - as a descendent of former property owners - possesses a certain in-depth knowledge about the township as a physical, political, and social place that others, especially newcomers, lack. Many descendants of the old families still occupy influential positions in civil society and township politics. They have higher levels of economic, political, social, and cultural capital.

In 2012, Mpo was working as a panel beater and was dreaming of opening his own business. Other young members of his milieu work in call centres in nearby Sandton. As semiskilled workers and routine white-collar workers they belong to the 'core working class' or the 'intermediate class' (Seekings and Nattrass, 2005). ${ }^{5}$ As such, they are better off economically than the majority of Alexandra residents who are unable to find any job in the formal economy.

\section{Opposition to the Alexandra Renewal Project}

Property ownership and expropriation were central to the discourses of the liberation movement (James et al., 2005, p. 827). During the early 1990s, a symbolically charged land reform program was developed; it was meant to redress past wrongs by restoring property rights, and it was expected to uplift the poor. The descendants of the former property owners in Alexandra made use of these discursive and legal resources. In the 1990s, 1,695 families made a successful group claim under the Restitution of Land Rights Act (1994). The

\footnotetext{
${ }^{5}$ Seekings and Nattrass (2005) define class in the Weberian tradition based on occupational groups. They developed a nine-fold classification scheme for South Africa.
} 
Commission for Restitution of Land Rights suggested that they should be compensated financially for their lost property with 50,000 South African rand (today about 3,000 euros). The families initially agreed to this deal, but later contested the compensation as insufficient and a betrayal. As one elder explained at an event organised for the youth of Alpoa, The new dispensation came into being and they said; 'Now, you people who lost your land during apartheid regime, you will get your land back.' But that was not to be. Instead of giving your land back, they started giving out 50,000, $50,000,50,000$ [rand]. They knew that our families are vulnerable! All of a sudden, we start losing focus. They made a hell of a lot of people give away their property at a very cheap cost.

Alexandra Land and Property Association (Alpoa), one of the key groups representing the interests of this milieu, resolved to make an appeal at the Land Claims Court. In the mid2000s, they achieved a court interdict. The interdict said that as long as the case was not closed, the Alexandra Renewal Project was not allowed to conduct any developments on the contested properties. The ARP could construct new housing on unused land at the periphery of Alexandra, but it was unable to upgrade the existing housing stock on the contested land. Many, among them representatives of the ARP, blamed Alpoa for having brought development in the township to a standstill. Among the critics of Alpoa who spoke with me on the matter were, amongst others, a political advisor to the ARP and the ARP's deputy director (see also Tau, 2015). After a complex land audit, an agreement between the land owners and the government was signed in 2016. It is foreseen that property restitution will be negotiated on a family-basis (Cox 2016).

\section{Linbro Park}


Linbro Park would be adjacent to Alexandra, but the two are separated by a highway and a former dumpsite. The two largest milieus in Linbro Park are white property owners and their black employees (domestic workers, gardeners, and handymen). Many of the domestic employees live in the backyard of their employers' properties. In the neighbourhood's internal social hierarchy, the domestic workers' rights within the neighbourhood are limited. They are not recognised as full residents (Heer, 2015a). Other people living in Linbro Park rent cottages and other housing from the white property owners. These tenants stem from diverse milieus. They have different racial and ethnic backgrounds, but tend to work in white collars jobs in nearby business areas like Sandton, Greenstone, or Linbro Park itself.

In terms of its ownership structure, Linbro Park has not yet experienced desegregation. In 2012 , only one black family owned one property, and there were a few Indian property owners. Linbro Park has long been primarily a residential suburb with few businesses. Now it is rapidly changing and transforming into a mixed-use area (Heer, 2015a).

\section{Property owners in Linbro Park}

During the Great Depression of the 1930s, the gold standard was abandoned, and South Africa experienced a sudden mining boom and economic upswing. Increased income and mobility (from car ownership) coupled with state subsidies for housing began a revolution in suburban space for the white milieus (Mabin, 2005, pp. 11-23). The then owner of Linbro Park's land recognised its economic potential, and he subdivided his farm into smaller agricultural holdings and sold them. The families that bought this land stem from European countries and are mostly English-speaking. Some are descendants of farmers; their parents or grandparents moved from Europe to rural Southern Africa as early as the $19^{\text {th }}$ century. Others came to work in the South African industries during apartheid. Elsa (ca. 55 years), for example, moved with her husband from Austria to South Africa in the 1970s. Their relocation 
was subsidized by direct state aid. At that time, the government was recruiting European immigrants to address the lack of skilled workers and out of fear that the white minority was diminishing (Segatti, 2011, p. 36).

Many of the apartheid-era immigrants were skilled handymen. The colour bar ensured that they had good jobs and salaries. In the 1970s, many white workers experienced a period of upward mobility into more skilled jobs (Crankshaw, 1996a, p. 652). Many Linbro Park residents started their own businesses; Elsa and her husband erected a branch of a company from Austria. Nowadays, the majority is self-employed. They own businesses in agriculture, light manufacturing, and in the tertiary sector. I did not collect data on their current income levels, but most can be assumed to fall under the best-earning classes of self-employed, which renders them overall as among Johannesburg's upper classes (Seekings and Nattrass, 2005). Similar to Alexandra, many households in Linbro Park are multi-generational. Many property owners host parents, siblings, and grown-up children on their land, usually in additional houses or cottages. The one-storey main houses range from estate-like villas to the functional houses of South African farms. Large lawns, gardens, and trees surround the houses on 2.5hectare properties, lending a sense of freedom and privacy to the inhabitants.

Their successful upward social mobility during apartheid, until today expressed in the spatial dimension of their lifestyle, was tightly linked to white privilege. In the same decades that Alexandra's non-white inhabitants were systematically denied citizenship rights, it gave European immigrants easy access to South African passports. They had access to well-funded government schools and universities. Still today, the property owners can afford good private schools and universities for their children, and therefore make sure that their favourable position is reproduced. They do not see their position as unmerited. In interviews, they emphasised that they earned their high social position through hard work - claims typical for groups who enjoyed white privilege (Gallagher, 2003). 


\section{Opposition to the Alexandra Renewal Project}

In the post-apartheid era, the Linbro Park property owners' lifestyle has become increasingly threatened. Because of the stalemate regarding land, the ARP began to look for land in the vicinity to construct public housing. Already in the late 1990s, Linbro Park residents believed that the municipality was considering their neighbourhood for RDP housing. The Regional Spatial Development Framework (2008/2009) eventually earmarked Linbro Park for a 'sustainable human settlement' development, in terms of the 'Breaking New Ground' policy (City of Johannesburg, 2008; City of Johannesburg, 2008/2009). The ARP eventually received funds from the national government for the purchase of properties, and in 2012 the Johannesburg Property Company (JPC), the local government branch responsible for land acquisitions, made purchase offers to some dozen property owners.

The property owners severely opposed selling. As they saw it, the construction of public housing would increase crime and lower property value. The neighbourhood association, the Linbro Park Community Association (LPCA), represented the residents in the public participation process (City of Johannesburg et al., 2010). The most important point for them concerned the urban design framework proposed for Linbro Park. The local government's plan assigned high residential densities for the neighbourhood under the framework. The property owners resisted (ultimately unsuccessfuly). Low density symbolised their suburban lifestyle, and they assumed that the lower the density, the wealthier would be the residents.

The property owners also tried to market their land to private developers, in an effort to steer development away from the state and into the private sector. In addition, they discussed the creation of a City Improvement District (CID). They hoped that such a selftaxing, self-governance organisation could enforce their by-laws if new black neighbours 
moved in, thus ensuring their power over the potential black newcomers. In 2012, the LPCA eventually desisted from the idea, not least because many residents were selling their properties to private investors. Alarmed by this 'expropriation threat', as the residents called it, the LPCA urged its members not to sell voluntarily, but to wait for expropriation, as they could receive a higher compensation this way. By 2014, two property owners had sold to the local government, but others were waiting for expropriation. It is yet unclear if and when the ARP will start building public housing. Linbro Park's property owners, though believe that their lifestyle has no long-term future in the competition for well-located urban land by private investors and the government.

\section{Comparing propertied citizenship}

In this comparative section, I draw attention to similarities between these two milieus in their opposition to the Alexandra Renewal Project (ARP), without neglecting the differences in the intentionality of their actions. The overall social position of the two groups is widely different in terms of income, culture, living conditions, and lifestyle, but what they share is a similar relationship to property. For Marx, property ownership was a key element of differentiation between classes. Indeed, for both milieus, defending their land is related to its significance as a means of production (but not only).

During the course of Alexandra's history, its property owners were usually not engaged in working class jobs, but made a living through businesses and collecting rents. The imaginations of the future by the contemporary generation, now the grandchildren and greatgrandchildren of the original buyers, still reflect this business orientation. As Mpo said, 'I want to be a business person. I don't want to work for someone else in the long run.' For many descendants of property owners, land and entrepreneurship continues to be interrelated. The fight for the restitution of land rights is, in their view, also a fight to reinstitute their 
economic position. Mpo told me too, 'They [Alpoa] are fighting to get their property back, so that they can run their own businesses. With a property, you don't have to go to look for a job, [...] you can't suffer.'

Likewise, for Linbro Park's property owners, land ownership was important for securing their economic position. They too rented out rooms and cottages. In times of economic hardship, landlordship ensured their ability to pay off bonds. In Lindbro Park, land and entrepreneurship are connected. Many keep their own business on the property. Being self-employed gives them a sense of independence, especially as many whites have begun to feel disadvantaged by Black Economic Empowerment, a government programme established in 2003 to redress Apartheid inequalities (Steyn and Foster, 2008, p. 41).

In their view, the "ARP threat" endangered their economic well-being, as they anticipated the deterioration of property prices. As one female owner told me, I don't agree with the plans of the ARP. I made an investment here, this is my retirement. My pension is not enough to live on. I don't qualify for a government pension because I have a property, although I paid my taxes all my life here. Only ministers get government pensions. [...] So why must I agree to low cost housing being built here?

Lefebvre (1996, p. 10) points out in his theory of space that space is not only a means of production, but also a means of reproduction. Indeed, for residents in the densely populated township Alexandra, access to housing is crucial for the ability to satisfy everyday needs, to build a family, and to lead a life considered descent. Most households of South Africa's 'core working class', to which many descendants of the property owners belong, are 'unprivileged relative to the higher classes, and privileged relative to the poorer half of South Africa's population' (Seekings and Nattrass, 2005, p. 44). From a relational point of view, Alexandra's former property owners can be seen as a lower middle class: They occupy an intermediary 
position between the poor and the 'black diamond' middle class (Donaldson et al. 2013) who tend to move to the suburbs. ${ }^{6}$ This intermediary milieu does not earn enough to finance a loan for a house in the suburbs nor are they poor enough to qualify for public housing. Because they lack access to housing many young people continue to live with their parents, although they may be in more or less stable partnerships, have children of their own, and want to start their own household. The descendants of the property-owning milieu have the privilege to appropriate discourses about land restitution and to make exclusionary claims about their entitlement to housing and property in Alexandra.

The local ANC and civil servants of the APR were opposed to Alpoa during the time of research. In public speeches politicians adopted the ANC's national discourse and spoke of land restitution as an opportunity to un-do apartheid's injustices to all black people, whether or not their ancestors had owned property (Walker, 2005, p. 808; James 2000). However, on the local level, the property owners fighting to get their land back are seen as a minority fighting to regain their privilege. They argued that because of the court interdict the ARP could not progress with the upgrade of the housing stock in Old Alexandra and was therefore blocking development for the majority of the population. As the deputy director of ARP expressed in an interview,

You see the Alpoa people are in the minority. But what about the rest of that population in Alex that lives there [on Alpoa's former properties]? They don't want those properties to be transferred back to this minority. So, politically the ANC is the majority party in Alex - they are not going to side with that minority of Alpoa members. Although the Alpoa people are very vocal and

\footnotetext{
${ }^{6}$ The term 'Black Diamonds' was introduced by the marketing industry to describe South Africa's affluent black middle class which emerged after 1994 (Southall, 2016).
} 
they shout and they've got access to political offices and politicians, they [the politicians] will say 'yes, land should be returned' but they won't do anything. For the Linbro Park property owners, their past rather posed a disadvantage for making claims of entitlement to their properties. They rather tried to avoid reference to the apartheid past and attempted to portray their arguments as unrelated to race. In interviews and at community meetings in 2011 and 2012 they argued that it was economic inequality that lay at the core of their resistance to living together with residents from Alexandra. There were various formulations: 'There is no racial issue, it's not a black-white issue, it's an economic issue'; 'It [poor and rich living together] doesn't work in South Africa, it doesn't work nowhere in the world.' They argued that because Alexandra's residents are poor and unemployed, they are also criminal; surely they would rob their wealthy new neighbours. The property owners appropriated discursive resources available in the public realm such as discourses on crime and security, the neoliberal market economy, and 'sustainable development' (Heer, 2015a).

Linbro Park's property owners had a strong emotional, social and political relationship to their properties. A further reason for their opposition to the ARP's plan was their lifestyle related to ideas of 'African nature' and 'outdoors'. Their childhood years had shaped these ideals and practices, as many had grown up on white farms.

I grew up in Namibia on a farm [...] Linbro Park was country, there was nothing here when we moved here. This was agricultural and it was the closest that we could get to farming. My husband had a business and also I wasn't a farmer who wanted to farm with cattle. But I just needed the space, the outdoors.

The property owners call their lifestyle 'country living in the city'; it is an expression often used in conversations, interview situations, and on their websites. This idea of 'nature' is lived through space-intensive and costly hobbies, especially horse riding. In Linbro Park, the social 
events related to horse riding were key sites for the building of neighbourhood sociality and sense of community. Here social status and identity become performed (Veblen, 2000; Bourdieu, 2010 [1984]).

Horseback riding and disposing of a lot of green space around their homes and bodies is interrelated with the Linbro Park's property owner's imagination of their social location within South African society. Ample space, 'African nature,' and the pursuit of spaceintensive hobbies made them prefer to stay in South Africa during a time when many other white South Africans were emigrating. For the property owners, the transformation of Linbro Park into a mixed neighbourhood with low cost housing, commercial developments, and improved roads constituted a threat to their lived space, and to their sense of self and belonging.

Critical political theorists have repeatedly pointed out how property bestows its owners with political influence. In the Greek agora only the 'pater familias' who had control over people (women, children, slaves) and the house was allowed to contribute to public debate (Arendt, 1959 [1958]). Also Habermas (2002) noted property ownership as a precondition for the participation in the European bourgeois public sphere. Although the times in which only citizens who owned property were allowed to vote had long gone, there is still a strong link between citizenship and property ownership. This is especially true in neighbourhood associations in cities across the world. Roy (2003) describes this contemporary link between property ownership and political citizenship as 'propertied citizenship'. That is to say, 'the right to the city is expressed through home ownership and ... politics is expressed through neighbourhood or homeowner associations' (Roy, 2009, p. 85). Also the Linbro Park property owners and Alpoa in Alexandra, they have the sense that owning property gives them a special right to influence the future of their neighbourhood, also at the expense of those who do not have property. 
This is best exemplified by the fact that the Linbro Park Community Association consisted exclusively of property owners. Other residents like tenants and domestic workers were not represented in neighbourhood politics and had no formal bodies to represent them. When referring to the 'community' in interviews, the property owners generally meant the other property owners. They excluded their non-property owning neighbours. Citizenship in Linbro Park - as the right to have a say in community affairs - was assumed as 'propertied'; those who owned land were confident in their own rights and in the justness of subjecting those without property to their political power (Ghertner, 2012, p. 1182; Roy, 2003).

A strong link between property and citizenship was similar for Alexandra's property owners before the expropriations. Owning freehold land was 'the touchstone of what they viewed as their "civilised" status, of their claim of difference from other urban Africans, and of their right to a measure of self-governance and political representation' (Bonner and Nieftagodien, 2008, p. 4). Acting as landlords and owning property gave them a sense of entitlement to govern the township. They saw and to a degree still see themselves as 'protectors' of the township. The contemporary struggle for property restitution is also a struggle for a resumed status as key actors in urban development. As propertied citizens, it seems to go without saying, that they have a moral right to direct the future of their community's development. If they receive back their titles, so they hope, they will be able to negotiate favourable deals with property investors and the government to construct new housing for themselves and tenants.

In 2016, when an agreement between the government and Alpoa was finally achieved, the 2,533 families received four options from which to choose. Former property owners could: get title deeds for the original stands of their forefathers; negotiate an alternative stand (for example on land bought by the ARP in Linbro Park); receive financial compensation; or participate in the form of public-private partnerships in the planned redevelopment of 
Alexandra (Cox, 2016). In a context where the right to the city was long contested, recognition of their land rights is a symbol and resource for their urban citizenship and leadership. It is yet unclear, though, what imagination of the urban future will guide the reinstated property owners as urban developers of Alexandra in the next years.

\section{Conclusion}

Importantly, this chapter has shown that property ownership confers privilege in Johannesburg. It provides owners with economic advantages - foremost is the stable income from rent (whether extracted formally or informally). Owning land also confers political privilege. It is related to a sense of being entitled to speak and decide about the future of neighbourhoods. The entitlements of propertied citizenship are, however, difficult to assess in quantitative forms. Hence, entitlements as such are often invisible in the analysis of middle classes and their various social, political, and economic impacts. The new analytical frameworks needed to grasp social differentiation in African countries should therefore also incorporate attention to the role of property in social stability and reproduction. (Neubert, 2005, p. 439).

Additionally, this example of two propertied milleus in South Africa demonstrates the need for caution in predicting the political behaviour of property-owning middle classes. The emergence of middle classes is thought by many to affect the redistribution of wealth and of political power. Many claim that middle classes possess a distinct political agency that is deployed in favour of a common good (Leeuwen, 2011, pp. 6-7).

Indeed, the two propertied milieus of Alexandra and Linbo Park constitute active, well-organised political actors. Their history of property ownership is entangled with the development of broad networks and the political knowledge necessary to navigate the bureaucratic and judiciary complexities of the post-apartheid state. In their political 
orientation, though, both are oriented towards the past and towards ensuring their own social reproduction at the clear expense of others. The Alexandra Renewal Project portrays both Alpoa and the LPCA as reactionary forces slowing down the township upgrading. Although the members of both interest groups, Alpoa and the LPCA, claim to morally support public housing for the poor, their interest in keeping and regaining their property ownership stands in contradiction to this. At least it did during the years 2010-16. If one assumes that the ANC's housing policy is 'progressive' (in the sense of being pro-poor and aimed at redistribution), one can judge both these milieus as 'conservative' forces. ${ }^{7}$

The African Development Bank (2011, p. 2) has described middle classes as 'Africa's future'. The Bank's report has generated substantial euphoria about the assumed positive effects of these groups on their societies' social development. However, this disjunctive comparison critically reassesses the trope of middle classes as 'progressive' agents. In the context outlined above, property ownership makes these social milieus rather conservative than progressive forces.

\footnotetext{
${ }^{7}$ Whether the ANC housing policies and redistributive welfare programs are really 'progressive' from the perspective of critical academia is another question which cannot be discussed here due to lack of space.
} 